\title{
Intrinsic expression of host genes and intronic miRNAs in prostate carcinoma cells
}

\author{
Kavleen Sikand ${ }^{1,2}$, Stephen D Slane ${ }^{3}$ and Girish C Shukla*1,2
}

\begin{abstract}
Address: ${ }^{1}$ Center for Gene Regulation in Health and Disease, Cleveland State University, 2121 Euclid Avenue, Cleveland, OH 44115, USA, ${ }^{2}$ Department of Biological, Geological and Environmental Sciences, Cleveland State University, 2121 Euclid Avenue, Cleveland, OH 44115, USA and ${ }^{3}$ Department of Psychology, Cleveland State University, 2121 Euclid Avenue, Cleveland, OH 44115, USA

Email: Kavleen Sikand - k.sikand@csuohio.edu; Stephen D Slane - s.slane@csuohio.edu; Girish C Shukla* - g.shukla@csuohio.edu

* Corresponding author
\end{abstract}

Published: 12 August 2009

Cancer Cell International 2009, 9:2I doi:10.1 186/1475-2867-9-2I

This article is available from: http://www.cancerci.com/content/9/I/2I

(C) 2009 Sikand et al; licensee BioMed Central Ltd.

This is an Open Access article distributed under the terms of the Creative Commons Attribution License (http://creativecommons.org/licenses/by/2.0), which permits unrestricted use, distribution, and reproduction in any medium, provided the original work is properly cited.
Received: 5 May 2009

Accepted: 12 August 2009

\begin{abstract}
Background: Recent data show aberrant and altered expression of regulatory noncoding micro (mi) RNAs in prostate cancer (PCa). A large number of miRNAs are encoded in organized intronic clusters within many protein coding genes. While expression profiling studies of miRNAs are common place, little is known about the host gene and their resident miRNAs coordinated expression in PCa cells. Furthermore, whether expression of a subset of miRNAs is distinct in androgen-responsive and androgen-independent cells is not clear. Here we have examined the expression of mature miRNAs of miR 17-92, miR 106b-25 and miR 23b-24 clusters along with their host genes CI3orf25, MCM7 and AMPO respectively in PCa cell lines.
\end{abstract}

Results: The expression profiling of miRNAs and host genes was performed in androgen-sensitive MDA PCa $2 b$ and LNCaP as well as in androgen-refractory PC-3 and DU I45 cell culture models of PCa. No significant correlation between the miRNA expression and the intrinsic hormoneresponsive property of PCa cells was observed. Androgen-sensitive MDA PCa $2 b$ cells exhibited the highest level of expression of most miRNAs studied in this report. We found significant expression variations between host genes and their resident miRNAs. The expressions of Cl3orf25 and miR 17-92 cluster as well as MCM7 and miR 106b-25 cluster did not reveal statistically significant correlation, thus suggesting that host genes and resident miRNAs may be expressed independent of each other.

Conclusion: Our results suggest that miRNA expression profiles may not predict intrinsic hormone-sensitive environment of PCa cells. More importantly, our data indicate the possibility of additional novel mechanisms for intronic miRNA processing in PCa cells.

\section{Background}

Prostate cancer $(\mathrm{PCa})$ is the most frequently diagnosed cancer and the second leading cause of death among American men [1]. The initial stage of PCa is androgendependent; hence, androgen blockade is the mainstay of therapy. Although androgen ablation therapy is effective in causing regression of prostate tumors, it produces only temporary remissions. The therapy eventually fails and PCa transits to the androgen-refractory or androgen-independent stage, a lethal form with a fatal prognosis [2]. 
Although several mechanisms have been proposed for explaining the pathogenesis of $\mathrm{PCa}$, the molecular mechanisms underlying the critical transition from androgendependence to androgen-independence of these tumors are poorly understood [reviewed in $[3,4]]$.

Regulatory noncoding microRNAs (miRNAs) play a critical role in the regulation of gene expression [5] and are potential candidates for studying their role in the progression of PCa to androgen-independent stage. miRNAs control gene expression by binding to the complementary sites in the 3' untranslated regions (3' UTRs) of target mRNAs and triggering either translational inhibition or mRNA degradation by a molecular mechanism which is a subject of intense investigation [6-9]. Aberrant expression of miRNAs has been correlated with the metastatic potential of melanoma [10,11], lymphoma [12-15], gastric [1618], ovarian [19-21], breast [22,23] and colorectal cancers [24-26]. Furthermore, miRNA expression or lack thereof, is associated with the disease progression of urogenital cancers including bladder, kidney $[27,28]$ and prostate $[29,30]$. Recent studies have demonstrated the aberrant expression of miRNAs in PCa tissues and cell lines [30-34] and differential expression of a miRNA in androgendependent and androgen-independent PCa cells [29]. Furthermore, androgen-regulated miRNAs may play a role in the transition of PCa to the androgen-independent stage [35]. Therefore, the role of miRNAs and their differential signature expression patterns in androgen-dependent and androgen-independent PCa cells requires a closer validation.

Gene expression modulating miRNAs are encoded in diverse genomic locations including intergenic regions, introns of protein-coding genes and introns/exons of noncoding RNA genes [36]. Approximately one third of experimentally identified human miRNAs are encoded in the introns of annotated protein coding genes $[37,38]$. It is likely that the intronic miRNAs are processed from the same primary transcript as the precursor mRNAs and thus, their expression levels are regulated by the expression of the host mRNA [39]. Interestingly, over $40 \%$ of human miRNAs are organized in evolutionarily conserved clusters suggesting that the clustering propensity of miRNAs may have a significant biological role [36-38,40,41]. Accumulating evidence suggests that clustered miRNAs are transcribed as polycistronic transcripts and thus have similar levels of expression. The miRNA clusters located in the introns of host genes present an especially interesting scenario by adding another level of co-regulation with the host mRNA expression. Although several miRNAs including some clustered miRNAs are functionally involved in the process of carcinogenesis [42-44], the phenomenon of miRNA clustering and their expression analysis vis-à-vis host gene expression has not been extensively investigated in PCa cells.

We investigated the expression of intronic miRNA clusters with respect to their host transcript expressions in PCa cells representing two distinct stages of PCa. The panel of PCa cell lines included two androgen-sensitive (MDA PCa $2 \mathrm{~b}$ and $\mathrm{LNCaP}$ ) and two androgen-independent (PC-3 and DU 145) cell lines. MDA PCa $2 \mathrm{~b}$ and LNCaP cell lines are derived from bone and lymph node metastasis respectively $[45,46]$. These cell lines express androgen receptor (AR) and PCa biomarker, prostate specific antigen (PSA) [47]. On the other hand PC-3 and DU 145 cell lines lack $\mathrm{AR}$, do not express PSA and do not have androgen response [47]. Host genes and their resident miRNA clusters were selected based on their potential relevance to cancer. Three intronic miRNA clusters were analyzed in this study: (i) miR 17-92 cluster, (ii) miR 106b-25 cluster and (iii) miR 23b-24 cluster.

The human miR 17-92 cluster is comprised of six miRNAs and is located in the third intron of C13orf25 gene at $13 q 31.3$ (Figure 1A). A growing body of evidence indicates that the miR 17-92 cluster acts as a potential oncogene and is mechanistically involved in tumorigenesis [48-50]. The miR 106b-25 cluster consists of three miRNAs and is located in the $13^{\text {th }}$ intron of MCM7 (minichromosome maintenance protein 7 ) gene on human chromosome 7 (Figure 2A). The miRNAs of this cluster share a high degree of sequence homology with the miRNAs of the miR17-92 cluster, thus suggesting the possibility of overlapping cellular functions of the two miRNA clusters. Furthermore, overexpression of MCM7 has been associated with PCa progression and recurrence [51]. In addition, miR 106b-25 is believed to be involved in a variety of cancers, suggesting its biological significance in carcinogenesis [16]. The miR 23b-24 cluster resides in intron 15 of the Aminopeptidase O (AMPO) gene on human chromosome 9 and consists of three member miRNAs: miR 23b, miR 24 and miR 27b (Figure 3A). The aberrant expression of miRNA members of miR 23b-24 cluster has been reported in some cancers [27]. miR 24 appears to inhibit erythroid differentiation [52] and a role for miR $27 \mathrm{~b}$ has been indicated in angiogenesis [53]. The differential expression of these miRNA clusters has not been studied systematically in prostate carcinogenesis. Furthermore, whether the member miRNAs are differentially expressed in androgen-dependent and androgenrefractory PCa is undetermined.

We hypothesized that these miRNAs may have unique expression patterns in androgen-sensitive and androgenrefractory cell culture models of PCa. Hence, we characterized the expression of the miRNAs and their host genes in 


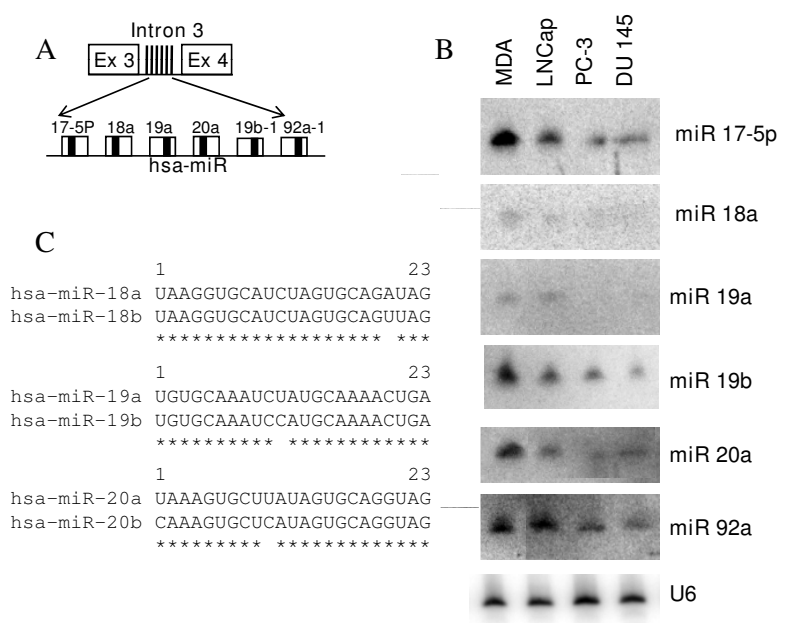

Figure I

miR I 7-92 cluster structure and expression. (A) Schematic representation of miR 17-92 cluster. Six miRNAs are expressed from intron 3 of $\mathrm{Cl} 3$ orf 25 gene (Ex = exon). The unfilled boxes correspond to precursor miRNAs and the solid thick black line within each box corresponds to mature miRNA. (B) The expression patterns of member miRNAs of miR 17-92 cluster in four PCa cell lines as evaluated by northern blotting (MDA = MDA PCa 2b). (C) Pairwise alignment of miRNAs. The figure reveals sequence similarities between miRNAs of paralogous clusters. Identical sequence between two miRNAs is shown by asterisks below the comparison and letters in bold correspond to sequence variation. miRs $18 \mathrm{~b}$ and $20 \mathrm{~b}$ shown in the alignments are derived from miR 106a-363 cluster on chromosome $X$. The miR 106a-363 cluster contains six miRNAs, namely, 106a, I8b, 20b, 19b-2, $92 \mathrm{a}-2$ and 363 . The mature forms of miR $19 \mathrm{~b}$ and miR $92 \mathrm{a}$ are expressed from both miRI7-92 and miR 106a-363 clusters.

PCa cell lines by northern blot and real-time quantitative PCR techniques.

\section{Results}

Expression Profiling of miR 17-92, 106b-25 and 23b-24 Clusters in Androgen-Dependent and AndrogenRefractory PCa Cell Lines by Northern Blotting

Two distinct stages of PCa are recapitulated in a variety of human PCa cell culture models. These cells lines are characterized in terms of their androgen sensitivity to account for their cell invasion and metastasis properties. As shown in Figures 1 to 3 , we characterized the expression of miRNA members of three clusters in PCa cell lines by Northern blotting. A summary of the relative miRNA expression is summarized in table 1 . The oncomir cluster 17-92 is encoded in the third intron of the C13orf25 gene (Figure 1A) [12]. As evidenced by the northern blotting experiment, miRNA members of the miR 17-92 cluster show a characteristic differential expression profile for each cell line studied (Figure 1B). All miRNA members of

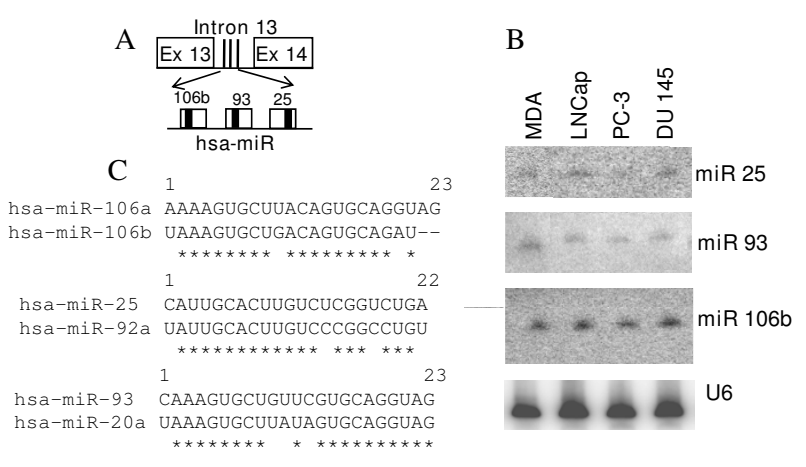

\section{Figure 2}

miR I 06b-25 cluster structure and expression. (A) Genomic organization of miR 106b-25 cluster in intron 13 of MCM7 gene. Precursor miRNAs are represented as unfilled boxes and the solid thick black line within each box corresponds to mature miRNA (Ex = exon). (B) Representative northern blot showing the expression of miR 106b-25 cluster in PCa cell lines (MDA = MDA PCa 2b). (C) Sequence comparison of miRNAs. Identical sequence between two miRNAs is shown by asterisks below the comparison and letters in bold correspond to sequence variation. miR 106a is expressed from miR 106a-363 cluster on chromosome $X$. miR 92a is derived from both miRI7-92 and miR I06a-363 clusters. miR 20a is also expressed from the miR I7-92 cluster.

this cluster were expressed in androgen-sensitive MDA PCa $2 \mathrm{~b}$ and LNCaP cells, albeit with varied levels (Figure $1 \mathrm{~B})$. However, not all the members were expressed in hormonal-refractory PC-3 and DU 145 cell lines e.g. miR18a and miR19a expression was not detected by northern blot analysis in these hormonal-refractory PCa cell lines. miRs 19b, 17-5p, 20a and 92a were found to be expressed in all four cell lines, albeit the expression was at lower levels in hormonal-refractory cells as compared to hormonesensitive cells (Figure 1B). The miR 17-92 cluster members on chromosome 13 share a high level of sequence homology with the miRNAs of two paralogous clusters, namely, miR 106b-25 and miR $106 a-363$ present on chromosome 7 and chromosome $\mathrm{X}$ respectively. Sequence homology between the miRNAs of these clusters is shown in Figures $1 \mathrm{C}$ and $2 \mathrm{C}$.

The miR 106b-25 cluster is encoded in intron 13 of MCM7 gene and contains three miRNA coding genes. The organization of miRNA genes in intron 13 is shown in Figure $2 \mathrm{~A}$. The northern blot analyses of miR $106 \mathrm{~b}-25$ cluster revealed similar levels of expression of all three miRNAs in the four cell lines (Figure 2B).

The miR 23b-24 cluster contains three miRNA coding genes located in the intron 15 of AMPO gene. The structure of miR $23 \mathrm{~b}-24$ cluster is shown in Figure $3 \mathrm{~A}$. The 


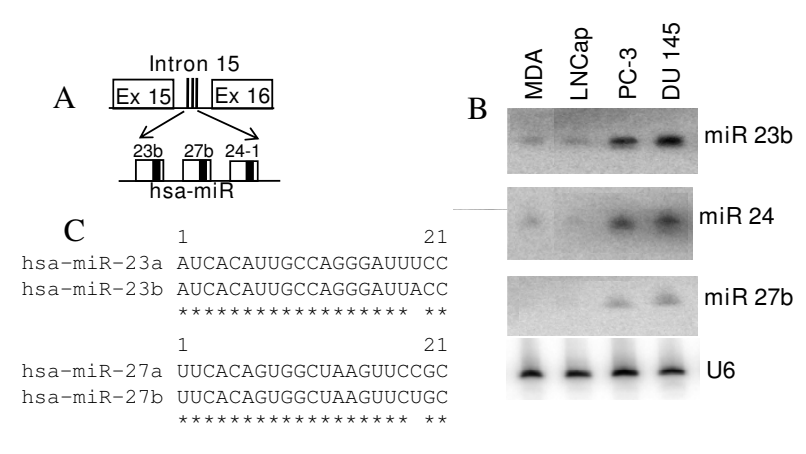

\section{Figure 3}

miR23b-24 cluster structure and expression. (A) Three miRNAs are encoded in intron 15 of AMPO gene (Ex = exon). Precursor miRNAs are represented as unfilled boxes and the solid thick black line within each box corresponds to mature miRNA. (B) Representative northern blot showing the expression of miR 23b-24 in PCa cell lines (MDA = MDA PCa 2b). (C) Aligned sequences of mature miRNAs revealing the high level of identity. Asterisks correspond to identical sequence between two miRNAs and bold letters corresponds to sequence variation. miRs $23 \mathrm{a}$ and $27 \mathrm{a}$ are expressed from the miR 23a-24 cluster on chromosome 19.

miRNA members of miR 23b-24 cluster demonstrated varied degree of expression levels as observed by signal intensities (Figure 3B). All three member miRNAs are expressed at higher levels in androgen-independent PC-3 and DU 145 cell lines as compared to androgen-dependent cells. The miR 23b-24 cluster on chromosome 9 shares sequence homology with miR 23a-24 cluster on chromosome 19 . The miR $23 \mathrm{~b}$ and $27 \mathrm{~b}$ sequences (miR 23b-24 cluster) differ by one nucleotide from the miR 23a and 27a sequences in the miR 23a-24 cluster (Figure 3C) and the two miRs 24 arising from both the clusters have an identical sequence. Hence, it is possible that the signal intensities of miRNA expression levels observed by northern blotting may correspond to some degree of cross hybridization to the paralog counterparts of miRNAs.

In summary, northern blot analyses of miRNA clusters in PCa cell lines demonstrated differential expression patterns of 12 miRNAs in the four PCa cell lines. Although it is a reliable technique, northern blotting cannot accurately estimate the expression of miRNAs having highly similar sequences. Hence, we sought to quantify the expression of these miRNAs as well as their host transcripts by reverse transcription and quantitative real-time PCR. To quantify the expression of mature miRNAs, we used TaqMan MicroRNA assays [54,55]. This technique can accurately analyze the expression of related miRNAs because it can discriminate between similar miRNAs differing by a single nucleotide [56].

\section{Expression of miR 17-92 Cluster and Host Transcript Cl3orf25}

All six miRNA members of the miR 17-92 cluster were significantly downregulated ( $\mathrm{p}<0.01$, table 2 \& Figure 4A) in LNCaP, PC-3 and DU 145 cells as compared to their expression in MDA PCa $2 \mathrm{~b}$ cells. The expression profile of the miR 17-92 cluster in LNCaP (androgen-dependent) cells was similar to that in DU 145 (androgen-independent) cells instead of matching the miR 17-92 expression profile in androgen-dependent MDA PCa $2 \mathrm{~b}$ cells (Figure $4 \mathrm{~A}$ ). The maximum downregulation (upto 20 fold) of miRNA members was observed in PC-3 (androgen-independent) cells and this expression profile was significantly different from that in the other three cell lines (table 2). This suggests that the miRNAs of the miR 17-92 cluster are differentially expressed among the four PCa cell lines and do not correlate with the intrinsic androgen response

Table I: Relative expression of miRNAs as determined by northern blots

\begin{tabular}{|c|c|c|c|c|c|c|c|}
\hline Cluster & Genomic Location & Host Gene & hsa-miR & MDA PCa 2b & LNCaP & PC3 & DUI45 \\
\hline \multirow[t]{6}{*}{ 17-92 } & $|3 q 3| .3$ & $\mathrm{Cl} 3$ orf25 & $17-5 p$ & ++++ & +++ & ++ & ++ \\
\hline & & & $18 \mathrm{a}$ & ++ & + & - & - \\
\hline & & & $19 a$ & ++ & + & - & - \\
\hline & & & $19 b$ & ++++ & +++ & + & + \\
\hline & & & $20 \mathrm{a}$ & +++ & ++ & + & + \\
\hline & & & $92 a$ & +++ & +++ & ++ & ++ \\
\hline \multirow[t]{3}{*}{$106 b-25$} & $7 q 22.1$ & MCM7 & 25 & + & + & + & + \\
\hline & & & 93 & + & + & + & + \\
\hline & & & $106 b$ & ++ & ++ & ++ & ++ \\
\hline \multirow[t]{3}{*}{$23 b-24$} & $9 q 22.32$ & AMPO & $23 b$ & + & + & +++ & +++ \\
\hline & & & 24 & + & + & ++ & ++ \\
\hline & & & $27 b$ & - & - & + & + \\
\hline
\end{tabular}

Hybridization signal intensities of each miRNA probe were normalized to the hybridization signal intensities of the U6 snRNA probe and the relative expression was scored on an arbitrary scale where $(-)$ and (++++) correspond respectively to undetectable and highest levels of relative expression of each miRNA in the four PCa cell lines. 
Table 2: Fold changes in the expressions of CI3orf25 mRNA and miR I7-92 cluster in PCa cell lines

\begin{tabular}{lllllll}
\hline & LNCaP/MDA & PC-3/MDA & DUI45/MDA & PC-3/LNCaP & DUI45/LNCaP & DUI45/PC-3 \\
\hline CI3orf25 & $3.35^{* *}$ & $0.29^{* * *}$ & $0.34^{* * * *}$ & $0.08^{* *}$ & $0.10^{* * *}$ & 1.16 \\
miR 17-5p & $0.15^{* *}$ & $0.43^{* *}$ & $0.24^{* * *}$ & $2.79 * * * *$ & $1.57^{*}$ & $0.56^{* * *}$ \\
miR 18a & $0.12^{* * * *}$ & $0.09^{* * * *}$ & $0.17^{* * * *}$ & 0.80 & 1.38 & $1.72^{*}$ \\
miR 19a & $0.19^{* *}$ & $0.04^{* *}$ & $0.14^{* * *}$ & $0.23^{* *}$ & $0.73^{*}$ & $3.16^{*}$ \\
miR 19b & $0.17^{* * * *}$ & $0.05^{* * * *}$ & $0.14^{* * * *}$ & $0.32^{* *}$ & $0.82^{*}$ & $2.55^{* * *}$ \\
miR 20a & $0.10^{* * * *}$ & $0.05^{* * * *}$ & $0.12^{* * * *}$ & $0.51^{* * * *}$ & $1.21^{*}$ & $2.35^{* * *}$ \\
miR 92a & $0.17^{* * *}$ & $0.55^{* * *}$ & $0.21^{* * *}$ & $3.20^{* * * *}$ & $1.25^{* *}$ & $0.39 * * *$
\end{tabular}

The fold change in the expression levels of the host gene and member miRNAs was determined by ratios of the expression between two cell lines (LNCaP/MDA, PC-3/MDA, DUI45/MDA, PC-3/LNCaP, DUI45/LNCaP and DUI45/PC-3). Asterisks indicate statistical significance as determined using the independent samples t-test.

$*_{p}<0.05, *_{p}<0.01, * * *_{p}<0.001$, **** $p<0.0001$

status of PCa cells. Remarkably, although there is a general decrease in the expression of miRNA members in the three cell lines as compared to their expression in MDA PCa $2 \mathrm{~b}$ cells, the fold decrease differs widely among cluster members. While the expression of miR 17-5p and miR 92a in PC-3 cells is reduced to approximately half their levels in MDA PCa 2b cells, the miRs 18a, 19a, 19b and $20 \mathrm{a}$ are downregulated by $10-20$ fold in PC-3 cells as compared to their expression in MDA PCa 2b cells (Figure $4 \mathrm{~A})$. Likewise, the member miRNAs in LNCaP and DU 145 cells are downregulated in the range of 4-9 folds as compared to their expression in MDA PCa $2 b$ cells. Within each cell line, the member miRNAs are expressed at different levels with miR 92a being the most abundant in all cell lines. It is noteworthy that miR $19 \mathrm{~b}$ and miR $92 \mathrm{a}$ are also derived from a paralogous cluster miR 106a-363 on chromosome X. Hence, the levels of miRs 19b and 92a estimated by qRT-PCR do not represent the amount of these miRNAs processed from the miR 17-92 cluster alone but instead, represent the total amount of these miRNAs derived from both clusters.

As seen in Figures $4 \mathrm{~A}$ and $4 \mathrm{~B}$, the expression profile of C13orf25 transcript in PCa cell lines is distinguishable from the expression profile of the resident miR 17-92 cluster in the same cell lines. While the C13orf25 mRNA is approximately 3 -fold upregulated ( $p<0.01$, table 2$)$ in LNCaP cells as compared to its expression in MDA PCa 2b, PC-3 and DU 145 cells, the member miRNAs of the miR 17-92 cluster are downregulated in LNCaP cells as compared to their expression in MDA PCa $2 \mathrm{~b}$ cells (Figures 4A \&4B). We applied Pearson product-moment correlation test on the C13orf25 and miR 17-92 expression data and found no significant correlation between the expression of the host gene C13orf25 and its resident miRNAs (table 3).

\section{Expression of miR 106b-25 Cluster and Host Transcript MCM7}

Next, we analyzed the expression of three miRNAs, namely miR 25, miR 93 and miR 106b, which are mem- bers of the miR 106b-25 cluster encoded in intron 13 of MCM 7 gene. The expression of the three miRNA members of the miR 106b-25 cluster was significantly reduced ( $\mathrm{p}<0.01$, table 4) in LNCaP, PC-3 and DU 145 cells as compared to their expression in MDA PCa 2b cells (Figure $5 \mathrm{~A}$ ). While all the three member miRNAs were downregulated by more than 2-fold in LNCaP and DU 145 cells, miR 106b was downregulated by approximately 5 -fold in PC-3 cells. miR 25 and miR 93 showed less than 2-fold downregulation in PC-3 cells as compared to their expression in MDA PCa 2b cells (Figure 5A). The 106b-25 miRNA cluster expression profile in androgen-dependent LNCaP cells was significantly different ( $\mathrm{p}<0.001$, table 4$)$ from that in another androgen-dependent cell line MDA PCa 2b. Moreover, the miRNA expression profile in PC-3 (androgen-independent) cells was also significantly different ( $\mathrm{p}<0.01$, table 4) from that in DU 145 (androgenindependent) cells. Hence, the expression of miR 106b-25 cluster does not appear to correlate with the intrinsic androgen responsiveness of PCa cells.

The comparison of the expression profile of MCM7 mRNA with the expression profile of the resident miR 106b-25 cluster shows no significant correlation between the host gene and intronic miRNA cluster expression (table 5). While the member miRNAs were significantly downregulated in LNCaP, PC-3 and DU 145 cells as compared to their expression in MDA PCa 2b cells (Figure 5A), the MCM7 mRNA was significantly upregulated in DU 145 cells ( $\mathrm{p}<0.01$, table 4$)$ and PC-3 cells ( $\mathrm{p}<0.0001$, table 4), and was expressed at similar level in LNCaP cells as compared to the expression in MDA PCa 2b cells (Figure $5 \mathrm{~B})$.

\section{Expression of miR 23b-24 Cluster and Host Transcript AMPO}

All three members of miR 23b-24 cluster, namely miR 23b, miR 24 and miR 27b were significantly downregulated by approximately 10 fold ( $\mathrm{p}<0.01$, table 6$)$ in LNCaP cells as compared to their expression in MDA PCa $2 \mathrm{~b}$ cells (Figure $6 \mathrm{~A}$ ). While miR $23 \mathrm{~b}$ and miR $27 \mathrm{~b}$ were sig- 


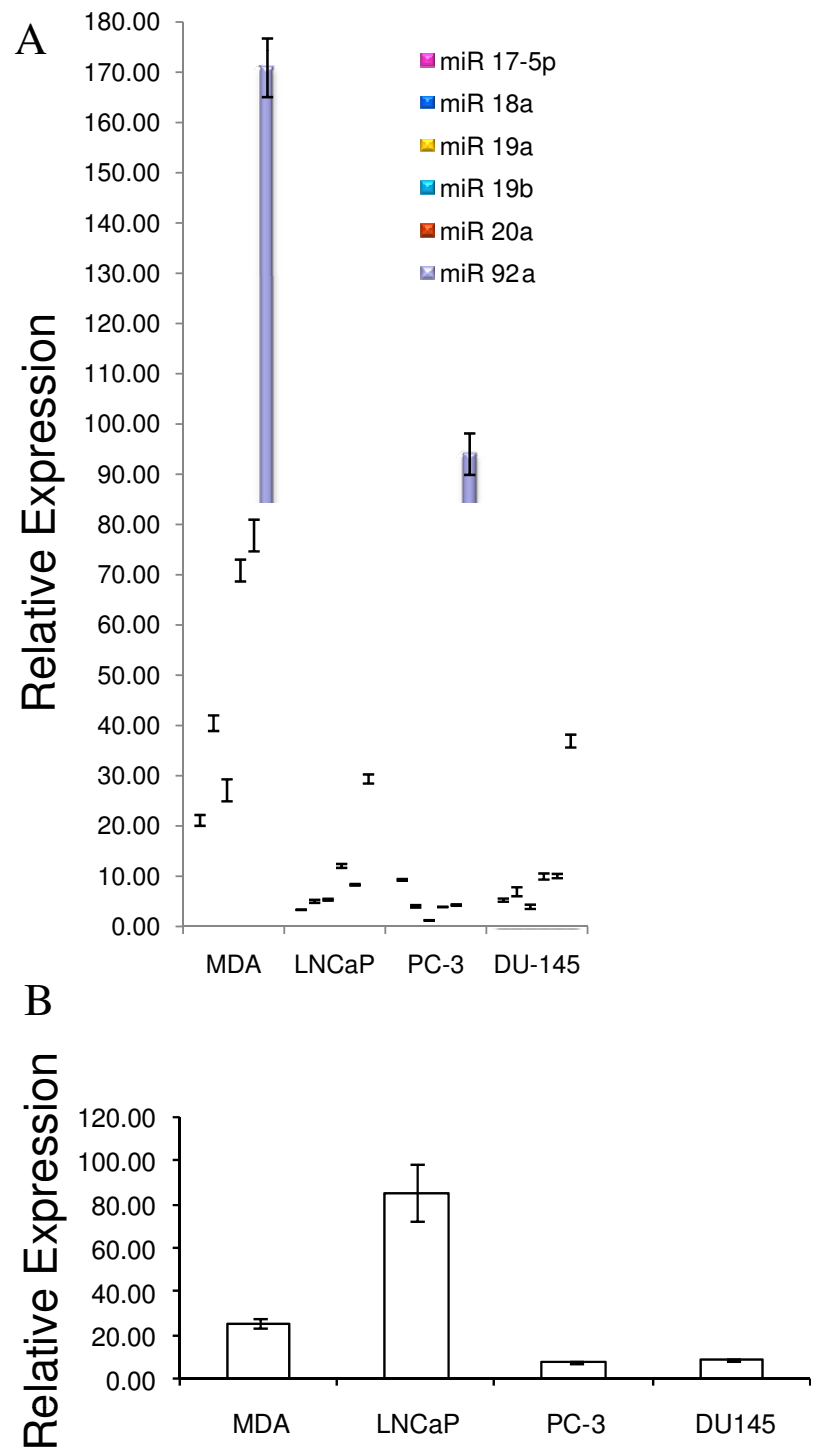

\section{Figure 4}

Quantitative real-time PCR expression profile of $\mathrm{miR}$ I 7-92 cluster and the host transcript Cl3orf25 in prostate cancer cell lines. (A) miRNA expression as determined by qRT-PCR. The relative expression of each miRNA is plotted as $2^{-\Delta C t}$ after normalization to sno66 expression. Each bar represents mean \pm SEM of at least 3 replicates. (B) qRT-PCR analysis of CI 3 orf25 mRNA expression. Each bar represents CI3orf25 mRNA expression normalized to GAPDH mRNA expression. Data are plotted as mean \pm SEM of six replicates. (MDA = MDA PCa $2 b)$.

nificantly downregulated in PC-3 and DU 145 cells, miR 24 was upregulated by about 2-fold in PC-3 cells and was expressed at almost the same level in DU 145 cells as compared to the expression in MDA PCa $2 \mathrm{~b}$ cells (Figure 6A, table 6). The miRNA expression profile is significantly dif- ferent ( $\mathrm{p}<0.01$, table 6$)$ in the four PCa cell lines, thus suggesting that miR 23b-24 cluster expression is not indicative of the intrinsic androgen responsive status of $\mathrm{PCa}$ cells. In all four PCa cell lines, miR 24 is the most abundantly expressed member miRNA. The mature miR 24 is also derived from a paralogous miR 23a-24 cluster on chromosome 19 comprising of miR 23a, miR 27a and miR 24. Hence, the level of miR 24 observed here presumably represents the total miR 24 expression derived from both paralogous clusters.

The expression of AMPO transcript was reduced by approximately 13 fold in LNCaP, PC-3 and DU 145 cells as compared to its expression in MDA PCa 2b cells (Figure $6 \mathrm{~B}$, table 6). This expression pattern matches the downregulation of all three member miRNAs of the miR 23b-24 cluster in LNCaP cells and the lower expression of miRs 23b and 27b in PC-3 and DU 145 cells as compared to the expression in MDA PCa 2b cells (Figure 6A). Pearson correlation analysis of the AMPO and miR 23b-24 expression data suggests a positive correlation between the expression of AMPO gene and miRs $23 \mathrm{~b}$ and $27 \mathrm{~b}$ but no significant correlation between the expression of AMPO and miR 24 (table 7). However, since the expression of miR 24 observed here could potentially represent the total miR 24 expression derived from miR 23b-24 cluster (residing in AMPO gene on chromosome 9) as well as its paralogous cluster miR 23a-24 (chromosome 19), the miR 24 expression may be disregarded in the interpretation of correlation with the host gene expression.

\section{Discussion}

The objectives of this study were: (1) to determine if a subset of miRNAs has a specific expression pattern in androgen-sensitive and androgen-independent PCa cell lines; (2) if there is a correlation in the expression levels of miRNAs and their host genes; and finally (3) to statistically examine if the expression of these miRNAs can delineate the intrinsic hormonal-sensitivity of the PCa cells studied here.

Several miRNA expression profiling studies have identified unique, differential miRNA expression patterns in different cancer types leading to the successful use of miRNA signatures for the molecular classification of cancer $[57,58]$. Hence, it was pertinent to search for miRNA expression profiles unique to androgen-dependent and androgen-independent PCa cells. However, whether miRNA expression profiles can predict the intrinsic androgen sensitivity of PCa cells is still an open question. Only a few studies so far have addressed the correlation, if any, between miRNA expression and intrinsic androgen responsive status of PCa cells. In this context, we investigated the expression of 12 miRNAs organized in three clusters (miR 17-92, miR 106b-25 and miR 23b-24) in 
Table 3: Pearson product-moment correlations of CI3orf25 mRNA expression with the expression of resident miRNAs.

\begin{tabular}{|c|c|c|c|c|c|c|c|}
\hline & & miRI7-5p & $\operatorname{miR} I 8 \mathrm{a}$ & $\mathrm{miR} / 9 \mathrm{a}$ & $\operatorname{miR} 19 b$ & $\operatorname{miR} 20 \mathrm{a}$ & $\operatorname{miR} 92 a$ \\
\hline \multirow[t]{2}{*}{ Cl3orf25 } & Pearson correlation coefficient & -0.343 & -0.126 & -0.004 & -0.036 & -0.098 & -0.366 \\
\hline & Significance (I-tailed) & 0.329 & 0.437 & 0.498 & 0.482 & 0.451 & 0.317 \\
\hline
\end{tabular}

*Correlation is significant at 0.01 level

two androgen-dependent (MDA PCa 2b and LNCaP) and two androgen-independent (PC-3 and DU 145) PCa cell lines using northern blotting and qRT-PCR analysis.

Northern blot analysis pointed out unique differences between the miRNAs of a given cluster. Some miRNAs appear to have unique expression in androgen-dependent and androgen-independent PCa cells (Figures 1, 2, 3, table 1). However, since probes used for northern blotting cannot distinguish between closely related miRNA sequences, we relied on the analysis of data generated by qRT-PCR. For all three miRNA clusters, member miRNAs are most abundantly expressed in MDA PCa 2b cells and are downregulated in LNCaP, PC-3 and DU 145 cell lines. In the miR 17-92 cluster, the expression profile of all the six member miRNAs in androgen-dependent MDA PCa $2 \mathrm{~b}$ cells is significantly distinguishable from that in another androgen-dependent cell line, LNCaP (Figure 4A \& table 2). Likewise, the expression profiles of miR 17-92 cluster members in PC-3 and DU 145 cells, both androgen-independent PCa cell types, significantly differ from each other (Figure $4 \mathrm{~A} \&$ table 2). This suggests that the expression of the miR 17-92 cluster does not correlate with the intrinsic androgen-responsive status of PCa cells. Similarly, in the miR 106b-25 cluster (Figure 5A, table 4) and in the miR 23b-24 cluster (Figure 6A, table 6), the expression profiles of member miRNAs do not match in either androgen-dependent cell lines (MDA PCa 2b and LNCaP) or two androgen-independent cell lines (PC-3 and DU 145).

None of the host genes studied here appears to contain consensus androgen responsive elements (ARE) and thus may not be potential direct targets of AR mediated transcriptional activation. To further confirm if host genes or miRNAs may respond to noncanonical androgen signal- ing, we treated LNCaP cells growing in charcoal stripped serum with dihydrotestosterone (DHT) and measured the expression of host genes and several miRNAs by qRT-PCR. The comparison of the expression profiles in untreated and DHT treated LNCaP cells did not demonstrate any statistically significant variation (data not shown), suggesting that the expression of host genes and miRNA clusters is not influenced by hormone signaling.

Although with the set of miRNAs studied here, a unique miRNA signature for androgen response status of $\mathrm{PCa}$ cells was not identified, a few investigations have reported the differential expression of miRNAs in androgendependent and androgen-independent PCa cells. A recent study suggested the potential of miRNA expression profiles to classify the clinical PCa samples according to their androgen dependence [30]. Further, Galardi et al. [33] reported that miR 221 and miR 222 are overexpressed in PC-3 cellular model of aggressive PCa as compared with LNCaP and 22R $v 1$ cell line models of slow growing carcinomas. These miRNAs were found to contribute to PCa pathogenesis by targeting the tumor suppressor p27kip1. Most recently, miR $146 \mathrm{a}$ and $\mathrm{miR} 125 \mathrm{~b}$ were reported to be differentially expressed in androgen-dependent PCa cells as compared to their expression in androgen- independent PCa cells [29,35]. Further investigations evaluating a large number of miRNAs are required to fully address the question of potential association between miRNA expression and intrinsic androgen sensitivity of PCa cells.

The expression of the miRNA clusters examined in this study has not been previously evaluated in PCa cells. Only one report has shown the overexpression of miR $17-5 \mathrm{p}$, miR 20a (miR 17-92 cluster) and miR 25 (miR 106b-25 cluster) in prostate tumor samples [31]. With regard to the

Table 4: Fold changes in MCM7 mRNA and miR 106b-25 expressions in PCa cell lines.

\begin{tabular}{lllllll}
\hline & LNCaP/MDA & PC-3/MDA & DUI45/MDA & PC-3/LNCaP & DUI45/LNCaP & DUI45/PC-3 \\
\hline MCM7 & 0.84 & $2.52^{* * * * *}$ & $1.46^{* * *}$ & $2.97^{* * * *}$ & $1.72^{* * * *}$ & $0.58^{* * * *}$ \\
miR 25 & $0.40^{* * *}$ & $0.70^{* *}$ & $0.55^{* *}$ & $1.75^{* * *}$ & $1.35^{* *}$ & $0.77^{* * *}$ \\
miR 93 & $0.26^{* * * *}$ & $0.73^{* *}$ & $0.42^{* * * *}$ & $2.72^{* * *}$ & $1.58^{* * *}$ & $0.58^{* * *}$ \\
miR 106b & $0.34^{* * * * *}$ & $0.18^{* * * *}$ & $0.47^{* * * *}$ & $0.55^{* * *}$ & $1.38^{* * *}$ & $2.50^{* * * * *}$
\end{tabular}

The fold change in the expression levels of mRNA and miRNAs was determined by ratios of the expression between two cell lines (LNCaP/MDA, PC-3/MDA, DUI45/MDA, PC-3/LNCaP, DUI45/LNCaP and DUI45/PC-3). Asterisks indicate statistical significance as determined using the independent samples t-test. $*_{p}<0.05$, ** $p<0.01$, *** $p<0.001$, ***** $p<0.0001$ 

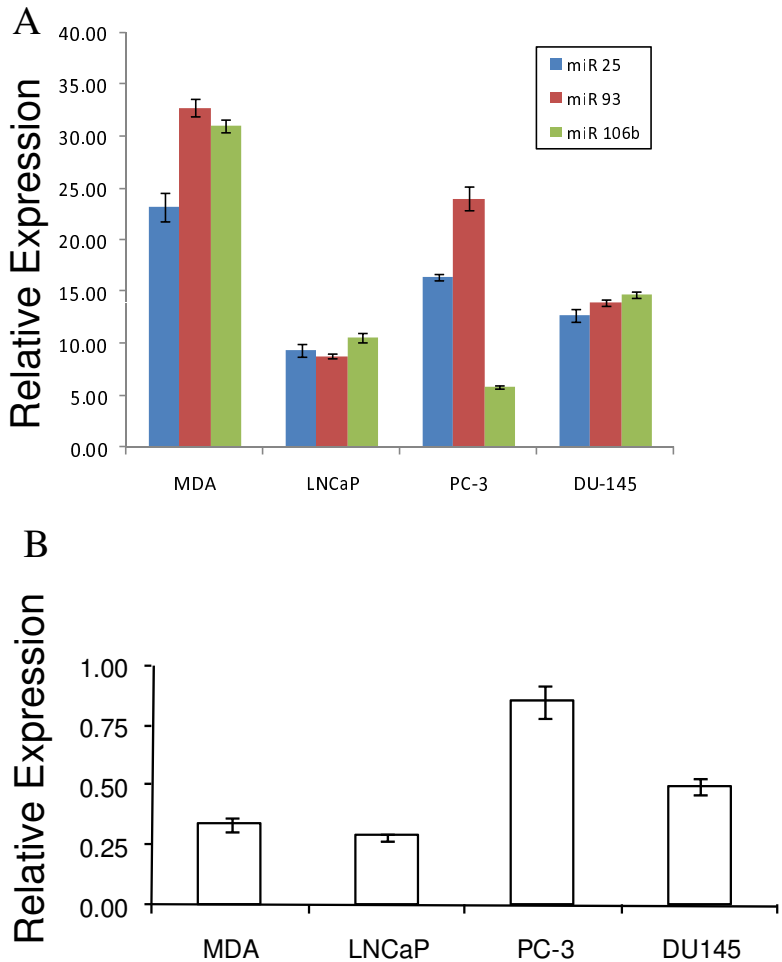

\section{Figure 5}

Expression profiles of member miRNAs of miR $106 \mathrm{~b}-$ 25 cluster and the host gene MCM7 in prostate cancer cell lines. (A) miRNA expression as determined by qRT-PCR. The relative expression of each miRNA is plotted as $2^{-\Delta \mathrm{Ct}}$ after normalization to sno66 expression. Each bar represents mean \pm SEM of at least 3 replicates. (B) qRT-PCR analysis of MCM7 mRNA expression. Each bar represents MCM7 mRNA expression normalized to GAPDH mRNA expression. Data are plotted as mean \pm SEM of six replicates. (MDA = MDA PCa 2b).

expression of miR 23b-24 cluster in $\mathrm{PCa}$, the downregulation of miR 23b and miR 27b in clinical PCa samples as compared to their expression in benign prostatic hyperplasia samples has been reported [30]. In the present study, we observed intriguing differences in miRNA expression across the four PCa cell lines. The most striking observation in our data is the magnitude of fold differences in the expression of miRNA cluster members across the four cell lines. The member miRNAs of the miR 17-92 cluster are downregulated by a range of 5 to 9 fold in LNCaP cells as compared to their expression in MDA PCa 2b cells; in PC-3 cells, miRs 18a, 19a, 19b and 20a are downregulated by 10-20 fold as compared to their expression in MDA PCa 2b cells and in DU 145 cells, downregulation of member miRNAs ranges from 4 to 8 fold (Figure $4 \mathrm{~A} \&$ table 2 ). Likewise, the member miRNAs of miR 106b-25 cluster are downregulated by 2-5 fold in LNCaP, PC-3 and DU 145 cells as compared to their expression in MDA PCa $2 \mathrm{~b}$ cells (Figure 5A \& table 4). In the $\operatorname{miR} 23 \mathrm{~b}-24$ cluster, the miR 24 expression measured by qRT-PCR does not estimate the miR 24 expression derived from miR 23b-24 cluster alone; instead, it represents the combined miR 24 expression from miR 23b-24 cluster and its paralog miR 23a-24 cluster present on chromosome 19. This could explain the high expression of miR 24 as compared to the expression of miRs $23 \mathrm{~b}$ and $27 \mathrm{~b}$ observed in our study. There is a highly significant downregulation (1.5 to 12 fold) of miRs $23 \mathrm{~b}$ and $27 \mathrm{~b}$ in LNCaP, PC-3 and DU 145 cell lines as compared to MDA PCa $2 \mathrm{~b}$ cell line (Figure 6A \& table 6 ). It is reasonable to speculate that such a magnitude of fold change in the expression of miRNAs across the four PCa cell lines may have significant biological consequences. It is possible that these clustered miRNAs may be playing important roles in the pathogenesis of PCa. In this context, some target mRNAs of the miR 17-92 cluster members have been experimentally validated. These targets include both tumor suppressors (p21, Bim, PTEN, Rb2/p130, Rbl2) as well as oncogenes (E2F1, AIB1) suggesting that the miRNAs of the miR 17-92 cluster can act as both oncogenes or tumor suppressors by modulating cell proliferation in a cell-type-specific manner depending on the set of target mRNAs that are expressed [42,49,59-62]. The experimentally validated targets of miR 106b-25 cluster also include the tumor suppressors, Bim and p21 as well as the oncogene, E2F1 [44,16]. Likewise, several mRNA targets of miR 23b-24 cluster, namely CYP1B1 and hALK4 have been identified $[52,63,64]$. It would be interesting to evaluate the expression of these targets in PCa cell culture models and clinical samples.

A few studies have compared the expression profiles of miRNAs and their host genes. Significant correlation between miRNA and host gene expression was reported suggesting the coregulation of intronic miRNA and host gene expression $[65,66]$. In this study, we profiled both

Table 5: Pearson product-moment correlations of MCM7 mRNA expression with the expression of resident miRNAs.

\begin{tabular}{lllll}
\hline & & miR 25 & miR 93 & miR I06b \\
\hline \multirow{2}{*}{ MCM 7 } & Pearson correlation coefficient & 0.089 & 0.216 & -0.582 \\
& Significance (I-tailed) & 0.455 & 0.392 & 0.209 \\
\hline
\end{tabular}

*Correlation is significant at 0.01 level 
Table 6: Fold changes in the expressions of the host transcript AMPO and the resident miR $23 \mathrm{~b}-24$ cluster in PCa cell lines.

\begin{tabular}{lllllll}
\hline & LNCaP/MDA & PC-3/MDA & DUI45/MDA & PC-3/LNCaP & DUI45/LNCaP & DUI45/PC-3 \\
\hline AMPO & $0.02^{* * * *}$ & $0.03^{* * * *}$ & $0.07^{* * * *}$ & $1.69 * * * *$ & $3.24^{* * * *}$ & $1.91^{* * *}$ \\
miR 23b & $0.09 * * * *$ & $0.17^{* * * * *}$ & $0.60^{* * * *}$ & $1.83^{* * * *}$ & $6.29 * * * *$ & $3.43^{* * * *}$ \\
miR 24 & $0.10^{* * * *}$ & $1.90^{* * * *}$ & 1.12 & $18.95^{* * * * *}$ & $11.20^{* * * *}$ & $0.59 * * * *$ \\
miR 27b & $0.07^{* *}$ & $0.19^{* *}$ & $0.33^{* * *}$ & $2.52^{* *}$ & $4.23^{* * *}$ & $1.67^{* * *}$
\end{tabular}

The fold change in the expression levels of the host gene and member miRNAs was determined by ratios of the expression between two cell lines (LNCaP/MDA, PC-3/MDA, DUI45/MDA, PC-3/LNCaP, DUI45/LNCaP and DUI45/PC-3). Asterisks indicate statistical significance as determined using the independent samples t-test. $*_{p}<0.05$, $*_{p} p<0.01$, **** $*_{p}<0.001$, ****** $<0.0001$.

the miRNA and host gene expression in four PCa cell lines. A positive correlation was observed between the expression of AMPO transcript and its resident miRs 23b and 27b (table 7). No significant correlation was observed between the expression of C13orf25 transcript and the expression of its resident miR 17-92 cluster members (table 3). Likewise the comparison of MCM7 mRNA
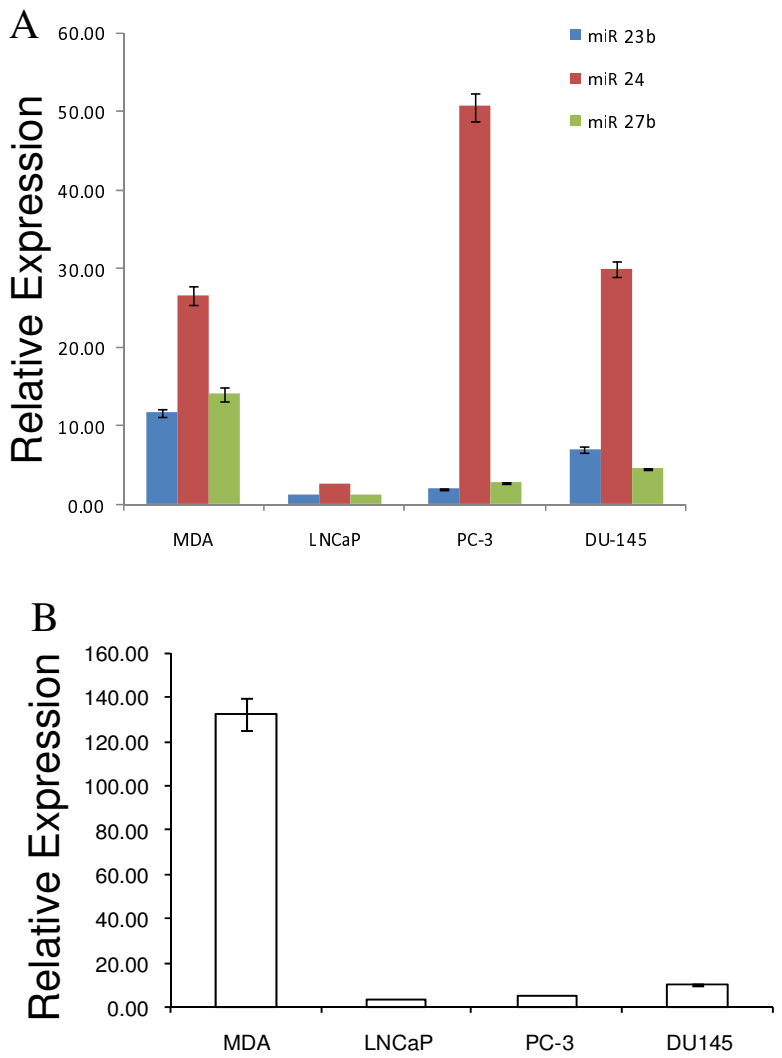

Figure 6

Differential expression of miR 23b-24 cluster and the host gene AMPO in prostate cancer cell lines. (A) miRNA expression as determined by qRT-PCR. The relative expression of each miRNA is plotted as $2-\Delta C t$ after normalization to sno66 expression. Each bar represents mean \pm SEM of at least 3 replicates. (B) qRT-PCR analysis of AMPO mRNA expression. Each bar represents AMPO mRNA expression normalized to GAPDH mRNA expression. Data are plotted as mean \pm SEM of six replicates. (MDA $=$ MDA PCa 2b). expression with the expression of its resident miR 106b25 cluster members shows no significant correlation (table 5). This appears to be in contrast to a previous finding which observed a perfect correlation between MCM7 mRNA expression and miR 106b-25 precursor miRNA expression [16]. Interestingly, the levels of miR 106b-25 precursor miRNAs do not appear to correlate perfectly with the levels of the mature forms of these miRNAs [16]. This observation is consistent with our findings as we have quantified the mature forms of miRNAs in the study.

Although we have shown the absence of correlation between the miRNA and the host transcript expression in two out of the three miRNA clusters, it may be a widespread phenomenon. Contrary to previous observations, our results suggest that host gene expression may not be a reliable indicator of the intronic miRNA expression. Our findings raise interesting questions regarding the biogenesis of intronic miRNAs. Since the expression of intronic miRNAs does not correlate with the expression of the host transcript, could it be that instead of being derived from the spliced intron of the host transcript, the resident miRNAs are transcribed independently from an alternative promoter in response to intracellular signaling? Another possibility could be that the resident miRNAs are co-transcribed with the host gene but additional, yet unknown, regulatory events occurring during the post-transcriptional processing of primary miRNAs to mature miRNAs may lead to diverse miRNA expression as compared to the host gene expression.

\section{Conclusion}

In conclusion, we studied the expression of 12 miRNAs from three clusters and compared their expression with the host gene expression in androgen-sensitive and androgen-refractory PCa cell lines. Our data indicate that the expression of none of these 12 miRNAs correlates with the androgen-dependent and androgen-refractory stages of the PCa cell culture models. MDA PCa 2b cells were unique in terms of overexpression of most of the miRNAs studied here. More importantly, in two out of the three miRNA clusters, we found no correlation between the host gene expression and resident miRNA expression, thus suggesting that the expression of some host genes 
Table 7: Pearson product-moment correlations of AMPO mRNA expression with the expression of resident miRNAs.

\begin{tabular}{|c|c|c|c|c|}
\hline & & $\mathrm{miR} 23 \mathrm{~b}$ & $\operatorname{miR} 24$ & $\operatorname{miR} 27 b$ \\
\hline \multirow[t]{2}{*}{ AMPO } & Pearson correlation coefficient & $0.87 I$ & -0.013 & $0.978^{*}$ \\
\hline & Significance (I-tailed) & 0.065 & 0.494 & 0.011 \\
\hline
\end{tabular}

*Correlation is significant at 0.05 level

and their resident miRNAs may be independent of each other. Our findings indicate the possibility of novel regulatory mechanisms for the processing of intronic miRNAs. Whether these mechanisms are cancer-specific is an open question. Further investigations directed to evaluate the complex phenomenon of intronic miRNA biogenesis in cancer cells may lead to the identification of new therapeutic targets.

\section{Methods}

\section{Cell Lines and Cell Culture}

The androgen-dependent human PCa cell lines MDA PCa $2 \mathrm{~b}$ and $\mathrm{LNCaP}$, and androgen-independent PCa cell lines PC-3 and DU145 were obtained from American Type Culture Collection (Manassas, VA). MDA PCa $2 \mathrm{~b}$ cells were cultured in BRFF-HPC1 medium (Athena Enzyme Systems, Baltimore, MD) supplemented with $20 \%$ fetal bovine serum (FBS) and antibiotics (100 units/ml of penicillin G sodium; $100 \mu \mathrm{g} / \mathrm{ml}$ streptomycin sulphate). LNCaP, PC-3 and DU145 cells were cultured in RPMI 1640 medium supplemented with $10 \%$ FBS, $2 \mathrm{mM} \mathrm{L}$ glutamine and antibiotics. All cell lines were maintained in a humidified $5 \% \mathrm{CO}_{2}$ atmosphere at $37^{\circ} \mathrm{C}$.

\section{RNA Extraction}

Total RNA was isolated from $80 \%$ confluent cells using Trizol reagent (Invitrogen, Carlsbad, CA) according to manufacturer's instructions. RNA yield and purity were determined spectrophotometrically at $260-280 \mathrm{~nm}$ and the integrity of RNA verified by electrophoresis through denaturing agarose gels stained with ethidium bromide.

\section{Northern Blotting}

Total RNA samples (30 $\mu$ g each) were separated on 15\% polyacrylamide gels containing $7 \mathrm{M}$ urea and electroblotted to nylon membranes (Hybond-XL, Amersham Biosciences). After UV cross-linking the RNA to nylon membrane at $120 \mathrm{~mJ}$ for 1 minute, the membrane was prehybridized in $10 \mathrm{ml}$ ULTRAhyb-Oligo hybridization buffer (Ambion) at $35^{\circ} \mathrm{C}$ for 30 minutes and then, hybridized in the same buffer with $\gamma-{ }^{32} \mathrm{P}$ labelled probes at $35^{\circ} \mathrm{C}$ overnight. DNA oligonucleotides complementary to mature miRNAs and U6 small nuclear RNA (snRNA) were used as probes. Probes were $5^{\prime}$ end-labelled using $[\gamma$ $\left.{ }^{32} \mathrm{P}\right]$ ATP and T4 polynucleotide kinase (Promega, Madison, WI). After overnight hybridization, the membrane was washed twice with $6 \times$ SSC for 15 minutes and $0.1 \%$
SDS with $6 \times$ SSC for 10 minutes, each at room temperature and then exposed to phosphor screen overnight. Bands were visualized by scanning the screens on Typhoon 9410 Variable Mode Imager (Amersham Biosciences). Expression of U6 snRNA was used as a loading control. Blots were stripped by incubating in $1 \%$ SDS at $65^{\circ} \mathrm{C}$ for 1 hour and reprobed.

\section{Reverse Transcription and Quantitative Real-Time (qRT) PCR Analysis of Mature miRNA Expression}

First strand CDNA was synthesized from 10 ng of total RNA using primers specific for mature miRNAs and small nucleolar RNA 66 (sno66). The miRNA-specific primers were obtained from TaqMan MicroRNA Assays (Applied Biosystems Foster City, CA). Reagents for cDNA synthesis were obtained from TaqMan MicroRNA Reverse Transcription kit (Applied Biosystems). For each sample, a 15 $\mu l$ reverse transcription (RT) reaction was set up containing 10 ng of total RNA, $1 \times$ RT buffer, 1 mM of dNTP mix, 50 units of MultiScribe reverse trancriptase, 3.8 units of RNase inhibitor and $3 \mu \mathrm{l}$ of miRNA-specific RT primer. The reactions were incubated in a thermal cycler (BIORAD PTC-100) at $16^{\circ} \mathrm{C}$ for 30 minutes, $42^{\circ} \mathrm{C}$ for 30 minutes, $85^{\circ} \mathrm{C}$ for 5 minutes and then held at $4{ }^{\circ} \mathrm{C}$. The 'reverse transcriptase minus' controls were also synthesized under the same conditions. In order to quantify the mature miRNAs and sno66 in each sample, the cDNAs were amplified using TaqMan MicroRNA Assays together with the TaqMan 2× Universal PCR Master Mix (Applied Biosystems Foster City, CA). Briefly, a $20 \mu \mathrm{l}$ reaction was set up containing $1.33 \mu \mathrm{l}$ product from RT reaction, $1 \mu \mathrm{l}$ of $20 \times$ TaqMan microRNA assay mix (mixture of miRNA-specific forward and reverse primers, and miRNA-specific TaqMan MGB probe labeled with FAM fluorescent dye) and $10 \mu \mathrm{l}$ of TaqMan $2 \times$ Universal PCR Master Mix. These reactions were dispensed into a 96-well optical plate and the plate was positioned in 7500 Real-time PCR System (Applied Biosystems) under the following conditions: $95^{\circ} \mathrm{C}$ for 10 minutes followed by 40 cycles of $95^{\circ} \mathrm{C}$ for 15 seconds and $60^{\circ} \mathrm{C}$ for 1 minute. Three replicates were performed per RT reaction together with the 'reverse transcriptase minus' and 'no template' controls. Duplicate PCRs were performed for all miRNAs in each RNA sample. The mean $C_{t}$ was determined from the replicates. Sno66 expression was used as an invariant control. The relative expression of each miRNA was calculated as $2^{-\Delta \mathrm{Ct}}$ where $\Delta \mathrm{Ct}=\mathrm{Ct}$ value of each miRNA in a sample - Ct value of sno66 in that 
sample. All experiments were repeated at least twice with three replicates and two independent RNA samples. All replicates provided similar results.

\section{Quantitative Real-Time PCR Analysis of Host Gene Expression}

Total RNA was isolated from the cells as described above. To remove DNA contamination from the RNA samples, $10 \mu \mathrm{g}$ of total RNA was incubated with 10 units of DNase I (Amplification grade; Invitrogen, Carlsbad, CA) at $37^{\circ} \mathrm{C}$ for 30 minutes. $1 \mu \mathrm{g}$ of DNase I treated RNA was reverse transcribed into cDNA using the ImProm-II Reverse Transcription System (Promega, Madison, WI). Briefly, a $20 \mu \mathrm{l}$ RT reaction was set up containing $1 \times$ ImProm-II reaction buffer, $5.5 \mathrm{mM} \mathrm{MgCl}_{2}, 0.5 \mathrm{mM}$ of each dNTP, 20 units of RNasin ribonuclease inhibitor, $0.5 \mu \mathrm{g}$ of oligo $\left(\mathrm{dT}_{15}\right)$ primer, $1 \mu \mathrm{l}$ of ImProm-II reverse transcriptase and $1 \mu \mathrm{g}$ of RNA. The RT reactions were incubated at $25^{\circ} \mathrm{C}$ for 5 minutes followed by $42^{\circ} \mathrm{C}$ for 1 hour and reverse transcriptase was inactivated by heating at $70^{\circ} \mathrm{C}$ for 15 minutes. Primers for real-time PCR were designed using the Primer Express software (v3.0; Applied Biosystems). The SYBR Green ER qPCR SuperMix Universal was obtained from Invitrogen and used for setting up real-time PCR reactions. In brief, a $20 \mu \mathrm{l}$ reaction was set up containing $1 \times$ SYBR Green Supermix (Invitrogen), $0.05 \mu \mathrm{M}$ of each of the forward and reverse primers, $50 \mathrm{nM}$ ROX dye and $2 \mu \mathrm{l}$ of template cDNA. The reactions were dispensed into 96well optical plates and the amplification was carried out in 7500 Real-time PCR System (Applied Biosystems) under the following conditions: $50^{\circ} \mathrm{C}$ for 2 minutes, $95^{\circ} \mathrm{C}$ for 10 minutes followed by 40 cycles of $95^{\circ} \mathrm{C}$ for 15 seconds and $60^{\circ} \mathrm{C}$ for 1 minute. Three replicates were performed per cDNA sample along with the 'reverse transcriptase minus' and 'no template' controls. Each PCR with three replicates was repeated twice. The specificity of amplification was confirmed by melting curve analysis and also by running the PCR reactions on 3\% agarose gels. Gene expression was quantified using the relative standard curve method. Different dilutions of cDNA synthesized from HeLa cells were used to plot the standard curves for each gene. Glyceraldehyde-3-phosphate dehydrogenase (GAPDH) expression was used as an internal control and the relative expression of each gene was normalized to GAPDH expression. Mean normalized expression of each gene \pm SE was calculated from the PCR replicates. All experiments were repeated at least twice with three replicates and two independent RNA samples and similar results were obtained. Following primers were used for the host gene expression analysis: (i) C13orf25 Forward ACACGCGGCCAGGTTAAG, Reverse CGCTGCAAAGATCGTTTGAG; (ii) MCM7 Forward CATGAGGCGTTACATAGCCATGT, Reverse CTCTCGCC TCATC TCCACGTA; (iii) AMPO Forward GGCCATGGGTGTGTA CCTCTA, Reverse GACCTATCCATCTGCTCCTTGGT; (iv)
GAPDH Forward ACCCACTCCTCCACCTTTGAC, Reverse TGTTGCTGTAGCCAAATTCGTT.

\section{Statistical Analysis}

The statistical analysis of expression levels of 12 miRNAs and three host precursor mRNAs and their coexpression in PCa cell lines was performed utilizing the SPSS package. The index of expression of each miRNA was $2^{-\Delta \mathrm{Ct}}$ after normalization to sno66 expression levels. The following analyses were conducted:

(i) Pairwise comparison of miRNAs selected from three clusters (17-92, 106b-25, 23b-24) across four PCa cell lines using independent samples t-test.

(ii) Pairwise comparison of the three selected host genes across four PCa cell lines using independent samples ttest.

(iii) The degree of linearly related expression levels between the host gene and resident miRNAs was determined by Pearson product-moment correlation coefficients.

\section{List of abbreviations}

(PCa): Prostate Cancer; (AR): Androgen Receptor; (PSA): Prostate Specific Antigen; (AMPO): Aminopeptidase O; (UTR): Untranslated Region; (MCM): Mini Chromosome Maintenance; (ORF): Open Reading Frame; (miRNA): MicroRNA.

\section{Competing interests}

The authors declare that they have no competing interests.

\section{Authors' contributions}

KS performed all the experiments. KS and GCS designed and analyzed the data. KS, SDS and GCS performed the statistical analysis. KS and GCS interpreted the statistical data and wrote the manuscript.

\section{Acknowledgements}

We like to thank anonymous reviewers for their comments. We thank Skip Heston for critical reading and valuable suggestions. This work was supported by ACS/IRG of CASE Comprehensive Cancer Center and in part by grant from DoD CDMRP W8IXWH-06-I-019I to GCS. Research in GCS laboratory is supported by grants from DoD and NSF.

\section{References}

I. Jemal A, Siegel R, Ward E, Hao Y, Xu J, Murray T, Thun MJ: Cancer statistics, 2008. CA Cancer J Clin 2008, 58:7I-96.

2. Denmeade SR, Isaacs IT: $\mathbf{A}$ history of prostate cancer treatment. Nat Rev Cancer 2002, 2:389-396.

3. Nelson WG, De Marzo AM, Isaacs WB: Prostate cancer. N EnglJ Med 2003, 349:366-38I.

4. Feldman BJ, Feldman D: The development of androgen-independent prostate cancer. Nat Rev Cancer 200I, I:34-45.

5. Bartel DP: MicroRNAs: genomics, biogenesis, mechanism, and function. Cell 2004, I I 6:28I-297. 
6. Pillai RS, Bhattacharyya SN, Filipowicz W: Repression of protein synthesis by miRNAs: how many mechanisms? Trends Cell Biol 2007, I7:118-126.

7. Lim LP, Lau NC, Garrett-Engele P, Grimson A, Schelter JM, Castle J, Bartel DP, Linsley PS, Johnson JM: Microarray analysis shows that some microRNAs downregulate large numbers of target mRNAs. Nature 2005, 433:769-773.

8. Bartel DP, Chen CZ: Micromanagers of gene expression: the potentially widespread influence of metazoan microRNAs. Nat Rev Genet 2004, 5:396-400.

9. Baek D, Villen J, Shin C, Camargo FD, Gygi SP, Bartel DP: The impact of microRNAs on protein output. Nature 2008, 455:64-7I.

10. Bemis LT, Chen R, Amato CM, Classen EH, Robinson SE, Coffey DG, Erickson PF, Shellman YG, Robinson WA: MicroRNA-I 37 targets microphthalmia-associated transcription factor in melanoma cell lines. Cancer Res 2008, 68: I362-1368.

II. Schultz J, Lorenz P, Gross G, Ibrahim S, Kunz M: MicroRNA let-7b targets important cell cycle molecules in malignant melanoma cells and interferes with anchorage-independent growth. Cell Res 2008, 18:549-557.

12. Ota A, Tagawa H, Karnan S, Tsuzuki S, Karpas A, Kira S, Yoshida Y, Seto $M$ : Identification and characterization of a novel gene, C13orf25, as a target for 13q31-q32 amplification in malignant lymphoma. Cancer Res 2004, 64:3087-3095.

13. He L, Thomson JM, Hemann MT, Hernando-Monge E, Mu D, Goodson S, Powers S, Cordon-Cardo C, Lowe SW, Hannon GJ, Hammond SM: A microRNA polycistron as a potential human oncogene. Nature 2005, 435:828-833.

14. Tagawa $\mathrm{H}$, Seto M: A microRNA cluster as a target of genomic amplification in malignant lymphoma. Leukemia 2005, 19:2013-2016

15. Takada S, Yamashita Y, Berezikov E, Hatanaka H, Fujiwara SI, Kurashina K, Watanabe H, Enomoto M, Soda M, Choi YL, Mano H MicroRNA expression profiles of human leukemias. Leukemia 2008, 22: $1274-1278$.

16. Petrocca F, Visone R, Onelli MR, Shah MH, Nicoloso MS, de MI, lliopoulos D, Pilozzi E, Liu CG, Negrini M, Cavazzini L, Volinia S, Alder $H$, Ruco LP, Baldassarre G, Croce CM, Vecchione A: E2FI-regulated microRNAs impair TGFbeta-dependent cell-cycle arrest and apoptosis in gastric cancer. Cancer Cell 2008, 13:272-286

17. Xia L, Zhang D, Du R, Pan Y, Zhao L, Sun S, Hong L, Liu J, Fan D: miRI $\mathrm{b}$ b and miR-16 modulate multidrug resistance by targeting BCL2 in human gastric cancer cells. Int J Cancer 2008, I 23:372-379.

18. Chan SH, Wu CW, Li AF, Chi CW, Lin WC: miR-2I microRNA expression in human gastric carcinomas and its clinical association. Anticancer Res 2008, 28:907-9II.

19. Iorio MV, Visone R, Di LG, Donati V, Petrocca F, Casalini P, Taccioli C, Volinia S, Liu CG, Alder H, Calin GA, Menard S, Croce CM MicroRNA signatures in human ovarian cancer. Cancer Res 2007, 67:8699-8707.

20. Nam EJ, Yoon H, Kim SW, Kim H, Kim YT, Kim JH, Kim JW, Kim S: MicroRNA expression profiles in serous ovarian carcinoma. Clin Cancer Res 2008, 14:2690-2695.

21. Zhang L, Volinia S, Bonome T, Calin GA, Greshock J, Yang N, Liu CG, Giannakakis A, Alexiou P, Hasegawa K, Johnstone CN, Megraw MS, Adams S, Lassus H, Huang J, Kaur S, Liang S, Sethupathy P, Leminen A, Simossis VA, Sandaltzopoulos R, Naomoto Y, Katsaros D, Gimotty PA, DeMichele A, Huang Q, Butzow R, Rustgi AK, Weber BL, Birrer MJ, Hatzigeorgiou AG, Croce CM, Coukos G: Genomic and epigenetic alterations deregulate microRNA expression in human epithelial ovarian cancer. Proc Natl Acad Sci USA 2008 105:7004-7009.

22. Foekens JA, Sieuwerts AM, Smid M, Look MP, de WV, Boersma AW, Klijn JG, Wiemer EA, Martens JW: Four miRNAs associated with aggressiveness of lymph node-negative, estrogen receptorpositive human breast cancer. Proc Natl Acad Sci USA 2008, | 05: | 302|-| 3026

23. Tavazoie SF, Alarcon C, Oskarsson T, Padua D, Wang Q, Bos PD, Gerald WL, Massague J: Endogenous human microRNAs that suppress breast cancer metastasis. Nature 2008, 45 I: | 47-I 52.

24. Schetter AJ, Leung SY, Sohn JJ, Zanetti KA, Bowman ED, Yanaihara N, Yuen ST, Chan TL, Kwong DL, Au GK, Liu CG, Calin GA, Croce CM, Harris CC: MicroRNA expression profiles associated with prognosis and therapeutic outcome in colon adenocarcinoma. JAMA 2008, 299:425-436.

25. Slaby O, Svoboda M, Fabian P, Smerdova T, Knoflickova D, Bednarikova M, Nenutil R, Vyzula R: Altered expression of miR-2 I, miR$3 I$, miR-I43 and miR-I45 is related to clinicopathologic features of colorectal cancer. Oncology 2007, 72:397-402.

26. Cummins JM, He Y, Leary RJ, Pagliarini R, Diaz LA Jr, Sjoblom T, Barad O, Bentwich Z, Szafranska AE, Labourier E, Raymond CK, Roberts BS, Juhl H, Kinzler KW, Vogelstein B, Velculescu VE: The colorectal microRNAome. Proc Natl Acad Sci USA 2006, 103:3687-3692.

27. Gottardo F, Liu CG, Ferracin M, Calin GA, Fassan M, Bassi P, Sevignani C, Byrne D, Negrini M, Pagano F, Gomella LG, Croce CM, Baffa R: Micro-RNA profiling in kidney and bladder cancers. Urol Oncol 2007, 25:387-392.

28. Neely LA, Rieger-Christ KM, Neto BS, Eroshkin A, Garver J, Patel S, Phung NA, McLaughlin S, Libertino JA, Whitney D, Summerhayes IC: A microRNA expression ratio defining the invasive phenotype in bladder tumors. Urol Oncol 2008 in press.

29. Lin SL, Chiang A, Chang D, Ying SY: Loss of mir-I 46a function in hormone-refractory prostate cancer. RNA 2008, 14:417-424.

30. Porkka KP, Pfeiffer MJ, Waltering KK, Vessella RL, Tammela TL, Visakorpi T: MicroRNA expression profiling in prostate cancer. Cancer Res 2007, 67:6130-6135.

31. Volinia S, Calin GA, Liu CG, Ambs S, Cimmino A, Petrocca F, Visone R, lorio M, Roldo C, Ferracin M, Prueitt RL, Yanaihara N, Lanza G, Scarpa A, Vecchione A, Negrini M, Harris CC, Croce CM: A microRNA expression signature of human solid tumors defines cancer gene targets. Proc Natl Acad Sci USA 2006, 103:2257-226I.

32. Ozen M, Creighton CJ, Ozdemir M, Ittmann M: Widespread deregulation of microRNA expression in human prostate cancer. Oncogene 2008, 27: I788-I793.

33. Galardi S, Mercatelli N, Giorda E, Massalini S, Frajese GV, Ciafre SA, Farace MG: miR-22I and miR-222 expression affects the proliferation potential of human prostate carcinoma cell lines by targeting p27Kip I. J Biol Chem 2007, 282:237I 6-23724.

34. Mattie MD, Benz CC, Bowers J, Sensinger K, Wong L, Scott GK, Fedele V, Ginzinger D, Getts R, Haqq C: Optimized high-throughput microRNA expression profiling provides novel biomarker assessment of clinical prostate and breast cancer biopsies. Mol Cancer 2006, 5:24.

35. Shi XB, Xue L, Yang J, Ma AH, Zhao J, Xu M, Tepper CG, Evans CP, Kung HJ, Vere White RW: An androgen-regulated miRNA suppresses Bak I expression and induces androgen-independent growth of prostate cancer cells. Proc Natl Acad Sci USA 2007, 104:19983-19988.

36. Griffiths-Jones S, Saini HK, van DS, Enright AJ: miRBase: tools for microRNA genomics. Nucleic Acids Res 2008, 36:DI54-DI58.

37. Griffiths-Jones S: Annotating noncoding RNA genes. Annu Rev Genomics Hum Genet 2007, 8:279-298.

38. Rodriguez A, Griffiths-Jones S, Ashurst JL, Bradley A: Identification of mammalian microRNA host genes and transcription units. Genome Res 2004, I4:1902-1910.

39. Cullen BR: Transcription and processing of human microRNA precursors. Mol Cell 2004, 16:86I-865.

40. Strauss WM, Chen C, Lee CT, Ridzon D: Nonrestrictive developmental regulation of microRNA gene expression. Mamm Genome 2006, 17:833-840

4I. Lee CT, Risom T, Strauss WM: Evolutionary conservation of microRNA regulatory circuits: an examination of microRNA gene complexity and conserved microRNA-target interactions through metazoan phylogeny. DNA Cell Biol 2007, 26:209-218.

42. O'Donnell KA, Wentzel EA, Zeller KI, Dang CV, Mendell JT: c-Mycregulated microRNAs modulate E2FI expression. Nature 2005, 435:839-843.

43. Liu Q, Fu H, Sun F, Zhang H, Tie Y, Zhu J, Xing R, Sun Z, Zheng X: miR- 16 family induces cell cycle arrest by regulating multiple cell cycle genes. Nucleic Acids Res 2008, 36:5391-5404.

44. Ivanovska I, Ball AS, Diaz RL, Magnus JF, Kibukawa M, Schelter JM, Kobayashi SV, Lim L, Burchard J, Jackson AL, Linsley PS, Cleary MA: MicroRNAs in the miR-106b family regulate p2I/CDKNIA and promote cell cycle progression. Mol Cell Biol 2008, 28:2167-2174.

45. Navone NM, Olive M, Ozen M, Davis R, Troncoso P, Tu SM, Johnston D, Pollack A, Pathak S, von Eschenbach AC, Logothetis CJ: Establish- 
ment of two human prostate cancer cell lines derived from a single bone metastasis. Clin Cancer Res 1997, 3:2493-2500.

46. Horoszewicz JS, Leong SS, Kawinski E, Karr JP, Rosenthal H, Chu TM, Mirand EA, Murphy GP: LNCaP model of human prostatic carcinoma. Cancer Res 1983, 43:1809-1818.

47. Navone NM, Logothetis CJ, von Eschenbach AC, Troncoso P: Model systems of prostate cancer: uses and limitations. Cancer Metastasis Rev 1999, 17:361-371.

48. Taguchi A, Yanagisawa K, Tanaka M, Cao K, Matsuyama Y, Goto H, Takahashi T: Identification of hypoxia-inducible factor-I alpha as a novel target for miR-17-92 microRNA cluster. Cancer Res 2008, 68:5540-5545.

49. Lu Y, Thomson JM, Wong HY, Hammond SM, Hogan BL: Transgenic over-expression of the microRNA miR-17-92 cluster promotes proliferation and inhibits differentiation of lung epithelial progenitor cells. Dev Biol 2007, 3 I 0:442-453.

50. Hayashita $Y$, Osada $H$, Tatematsu $Y$, Yamada $H$, Yanagisawa K, Tomida S, Yatabe Y, Kawahara K, Sekido Y, Takahashi T: A polycistronic microRNA cluster, miR-17-92, is overexpressed in human lung cancers and enhances cell proliferation. Cancer Res 2005, 65:9628-9632.

5I. Padmanabhan V, Callas P, Philips G, Trainer TD, Beatty BG: DNA replication regulation protein $\mathrm{Mcm} 7$ as a marker of proliferation in prostate cancer. J Clin Pathol 2004, 57: I057-1062.

52. Wang Q, Huang Z, Xue H, Jin C, Ju XL, Han JD, Chen YG: MicroRNA miR-24 inhibits erythropoiesis by targeting activin type I receptor ALK4. Blood 2008, I I I:588-595.

53. Kuehbacher A, Urbich C, Dimmeler S: Targeting microRNA expression to regulate angiogenesis. Trends Pharmacol Sci 2008, 29:12-15.

54. Jiang J, Lee EJ, Gusev Y, Schmittgen TD: Real-time expression profiling of microRNA precursors in human cancer cell lines. Nucleic Acids Res 2005, 33:5394-5403.

55. Lee EJ, Schmittgen TD: Comparison of RNA assay methods used to normalize cDNA for quantitative real-time PCR. Anal Biochem 2006, 357:299-301.

56. Schmittgen TD, Lee EJ, Jiang J, Sarkar A, Yang L, Elton TS, Chen C: Real-time PCR quantification of precursor and mature microRNA. Methods 2008, 44:31-38.

57. Esquela-Kerscher A, Slack FJ: Oncomirs - microRNAs with a role in cancer. Nat Rev Cancer 2006, 6:259-269.

58. Calin GA, Croce CM: MicroRNA signatures in human cancers. Nat Rev Cancer 2006, 6:857-866.

59. Hossain A, Kuo MT, Saunders GF: Mir-17-5p regulates breast cancer cell proliferation by inhibiting translation of AIB I mRNA. Mol Cell Biol 2006, 26:8|9|-820I.

60. Wang Q, Li YC, Wang J, Kong J, Qi Y, Quigg RJ, Li X: miR-I7-92 cluster accelerates adipocyte differentiation by negatively regulating tumor-suppressor $\mathbf{R b 2} / \mathbf{p}$ I 30. Proc Natl Acad Sci USA 2008, 105:2889-2894.

6I. Fontana L, Fiori ME, Albini S, Cifaldi L, Giovinazzi S, Forloni M, Boldrini R, Donfrancesco A, Federici V, Giacomini P, Peschle C, Fruci D: Antagomir-17-5p abolishes the growth of therapy-resistant neuroblastoma through p2I and BIM. PLoS ONE 2008, 3:e2236.

62. Xiao C, Srinivasan L, Calado DP, Patterson HC, Zhang B, Wang J, Henderson JM, Kutok JL, Rajewsky K: Lymphoproliferative disease and autoimmunity in mice with increased miR-17-92 expression in lymphocytes. Nat Immunol 2008, 9:405-4I4.

63. Tsuchiya Y, Nakajima M, Takagi S, Taniya T, Yokoi T: MicroRNA regulates the expression of human cytochrome P450 IBI. Cancer Res 2006, 66:9090-9098.

64. Fukuda $\mathrm{Y}$, Kawasaki H, Taira K: Exploration of human miRNA target genes in neuronal differentiation. Nucleic Acids Symp Ser (Oxf) 2005, 49:34I-342.

65. Baskerville S, Bartel DP: Microarray profiling of microRNAs reveals frequent coexpression with neighboring miRNAs and host genes. RNA 2005, I I:24I-247.

66. Liang Y, Ridzon D, Wong L, Chen C: Characterization of microRNA expression profiles in normal human tissues. BMC Genomics 2007, 8:166.
Publish with Biomed Central and every scientist can read your work free of charge

"BioMed Central will be the most significant development for disseminating the results of biomedical research in our lifetime. "

Sir Paul Nurse, Cancer Research UK

Your research papers will be:

- available free of charge to the entire biomedical community

- peer reviewed and published immediately upon acceptance

- cited in PubMed and archived on PubMed Central

- yours - you keep the copyright

Submit your manuscript here:

http://www.biomedcentral.com/info/publishing_adv.asp
BioMedcentral 